\title{
A Bioactive Polyphenolic Constituent in the Bark of Pterocarpus indicus, Willd and Its Effects on Animal Cell Phenotypes in Vitro
}

\author{
Setsuo Takeuchi, Yoshiki Kono, Takeo Nambata, \\ Noriko Terada, Hadiman, ${ }^{*}$ Ryoko Watanabe, Yoshikatsu Suzuki, \\ Akira Kawarada and Sasongko S. Adisewojo* \\ The Institute of Physical and Chemical Research, \\ 2-1 Hirosawa, Wako-shi, Saitama 351-01, Japan \\ * The Institute for Natural Sciences, Padjadjaran University, \\ Jaran Singaperbangsa, Bandung, Indonesia
}

Received September 6, 1985

\begin{abstract}
Earlier isolated plant polyphenol PI, which is carcinostatic on mice implanted with Ehrlich carcinoma [S. Takeuchi et al., Agric. Biol. Chem., 50, 569 (1986)], showed transient, nonspecific, non-cytotoxic growth inhibition in vitro on both normal and malignant cells. Examination of its effects on alteration of native and TPA-induced in vitro phenotypes revealed that PI suppress both the plasmin and ODC activities of the cells that increase with spontaneous malignancy, and also the TPA-induced ODC activity increase. TPA-induced decrease of ${ }^{125}$ I-mEGF-binding ability was reversed by PI, to larger extent in the HeLa cells than in the untransformed RME-5-3-1 cells.
\end{abstract}

A woody legume, Pterocarpus indicus, Willd, contains a bioactive polyphenolic substance, PI, isolated from the bark extract as a brownish powder. ${ }^{1)}$ PI gave a single peak in HPLC and its homogeneity was fonfirmed by the single symmetrical sedimentation boundary in analytical ultracentrifugation. The molecular weight was approximately 20,400 . Though PI seemed to be a polymeric flavanol, its homogeneity and its molecular weight larger than those of most of this group indicate some unusual characteristic. PI had a strong antiplasmin activity, and also a carcinostatic effect on mice bearing ascites Ehrlich carcinoma. ${ }^{1}$

This paper deals with later studies on the bioactivities of PI, especially those on in vitro phenotypes closely related to cell transformation, which are the suppressive effect on the cellular plasmin activity, the influence on the cellular ODC activity, native or TPA-induced, and the interaction between PI and TPA on the variation of ${ }^{125} \mathrm{I}$-mEGF-binding ability of cells. Many malignant animal cells secrete a plasminogen activator $^{2 \sim 4)}$ that activates plasminogen to active plasmin. ${ }^{5,6)}$ The mode of induction of this activator appears to be closely related to malignant cell transformation of various origins. Ornithine decarboxylase (ODC) participates in the growth regulation of animal cells through polyamine biosynthesis, ${ }^{7,8)}$ and the variation of ODC activity is said to be closely related to the phenotypic malignancy of cells. ${ }^{9,10)}$ The epidermal growth factor (EGF) secreted from many varieties of animal cells, is said to control metabolic regulation by binding with a specific receptor (EGF-R) on cell surfaces. ${ }^{11,12)}$ Its amount in transformed cells is often abnormally lower or higher than that in normal cells. ${ }^{11 \sim 16,25)}$ In our previous work, for example, that untransformed RME-5-3-1 cells bind EGF strongly, but the transformed RME-5-1/TMT cells do not. ${ }^{16)}$ 12-O-tetradecanoyl-phorbol-13-acetate (TPA) is a potent tumor promotor that causes pronounced perturbations of cellular phenotypes, ${ }^{17 \sim 22)}$ with induction of plasminogen activator in cells, transient enhancement of the ODC activity, and reduction of EGF-binding 
by cells.

\section{MATERIALS AND METHODS}

Isolation of PI. ${ }^{1)}$ Five hundred grams of the powdered bark of Pterocarpus indicus, Willd was extracted with $70 \%$ aqueous methanol. The filtered extract was concentrated and adsorbed on a Sephadex LH20 column $(4 \times 70 \mathrm{~cm})$, which was washed with water and eluted with $90 \%$ aqueous dioxane. The concentrated active fraction was dialyzed against distilled water, dried, and dissolved in a small volume of $90 \%$ aqueous methanol for preparative HPLC (column: Shodex Polymerpak D-2014, $2 \times 55 \mathrm{~cm}$, solvent: $90 \% \mathrm{MeOH}$, flow rate: $8 \mathrm{ml} / \mathrm{min}$ ). The main peak at $14 \mathrm{~min}$ retention time in HPLC was lyophilized after dialysis. PI was obtained as a brownish powder $(350 \mathrm{mg})$ and gave a single HPLC peak.

Cells and culture media. RME-5-3-1 cells: Untransformed diploidal fibroblasts of RME-5-3-1 cells used in this study were established in our laboratory from $\mathrm{C} 3 \mathrm{H} /$ He mouse embryos by long-term culture with a benzaldehyde-containing medium. ${ }^{16)}$ RME-5-1/TMT cells: Transformed malignant RME-5-1/TMT cells ${ }^{16)}$ were reestablished from the tumors in $\mathrm{C} 3 \mathrm{H} / \mathrm{He}$ mouse induced by implantation of spontaneously transformed RME-5-1 cells, ${ }^{16)}$ which were established from the same embryos as RME-5-3-1 cells in normal medium. Culb TC/R/TC cells: Malignant Culb TC/R/TC cells are rat liver cells transformed by treatment with 4-nitroquinoline- $N$-oxide, in vitro, back-transplanted into rats, and reestablished. ${ }^{23)}$ This cell line was a gift from the late Prof. H. Katsuta of Dokkyo University. HeLa cells: This cell line derived from a human cervical carcinoma was a gift from Prof. M. Umeda of the Yokohama City University School of Medicine.

DM-160 basal medium (Kyokuto Pharm., Tokyo) containing $10 \%$ fetal bovine serum (FBS, Gibco), 50 units $/ \mathrm{ml}$ penicillin $\mathrm{G}$ and $50 \mu \mathrm{g} / \mathrm{ml}$ streptomycin was used in all of the experiments except for the ${ }^{125} \mathrm{I}-\mathrm{mEGF}$ binding assay, in which Dulbecco's modified Eagle's media (DMEM, Gibco) containing $10 \%$ calf serum (Gibco) and antibiotics as above were used.

Growth curves. Growth curves of cells at $37^{\circ} \mathrm{C}$, in a humidified atmosphere of $5 \% \mathrm{CO}_{2}$, were obtained by counting the viable cell numbers at intervals by staining with Crystal Violet in a $60 \mathrm{~mm}$ dish (Corning) with $4 \mathrm{ml}$ of medium, which was renewed every other day. All experiments were done in triplicate.

Plasmin assay by fibrin overlay method. Cellular plasmin activity was examined by the fibrin overlay method of Jones et al. ${ }^{5)}$ RME-5-1/TMT cells were implanted into $60 \mathrm{~mm}$ dishes, to a density of about $10^{5}$ cells/dish and cultured in a $5 \% \mathrm{CO}_{2}$ incubator at $37^{\circ} \mathrm{C}$ for 4 days. Each culture to be overlaid was washed twice with PBS (-). The cells were then partially removed with a rubber policeman at the center of the plate in a criss-cross $5 \mathrm{~mm}$ in width, for easy observation. Then the fibrin-agarose mixed medium, which contained an appropriate amount of a test sample, was overlaid on the cells, and the dish was further incubated at $37^{\circ} \mathrm{C}$ for $48 \mathrm{hr}$. The cloudy fibrin-agarose overlay on the cells was cleared by plasmin activated by malignant cells.

Ornithine decarboxylase $(O D C)$ assay. The ODC activity of the cells was measured by the release of ${ }^{14} \mathrm{CO}_{2}$ from DL-[1- $\left.{ }^{14} \mathrm{C}\right]$-ornithine $(5.4 \mathrm{mCi} / \mathrm{mm}$, New England Nuclear), essentially by the method by Russel and Sny$\mathrm{der}^{8)}$ and O'Brien et al. ${ }^{24)}$ To assay by measurement of ${ }^{14} \mathrm{CO}_{2}$ release, quiescent RME-5-3-1 cells trypsinized from the confluent culture were suspended in DM-160 medium containing 10\% FBS (approximately $3 \times 10^{6}$ cells $/ 100 \mathrm{~mm}$ dish) and cultured in a $5 \% \mathrm{CO}_{2}$ incubator at $37^{\circ} \mathrm{C}$, with or without addition of PI $(12.5 \mu \mathrm{g} / \mathrm{ml})$, TPA $(500 \mu \mathrm{g} / \mathrm{ml})$ or both. The cells were collected at intervals with a rubber policeman and homogenized in $1 \mathrm{ml}$ of extracting solution. ${ }^{16)}$ To measure ${ }^{14} \mathrm{CO}_{2}$ release, solution containing $0.4 \mu \mathrm{mol}$ ornithine, $100 \mu \mathrm{mol}$ sodium phosphate, $0.4 \mathrm{ml}$ cell extract, and added PI ( 0 to $50 \mu \mathrm{g} / \mathrm{ml}$ ) was preincubated at $37^{\circ} \mathrm{C}$ for $10 \mathrm{~min}$, then $0.25 \mu \mathrm{Ci}$ of labeled ornithine was added to give a final volume of $2.0 \mathrm{ml}$ in a $30-\mathrm{ml}$ Erlenmeyer flask. After $30 \mathrm{~min}$ of incubation, the reaction was stopped by addition of $1 \mathrm{ml}$ of $2 \mathrm{M}$ citric acid. $\mathrm{CO}_{2}$ released during incubation was trapped in $0.2 \mathrm{ml}$ of ethanolamine contained in the polyethylene center well attached to the rubber stopper of the flask. The center well was transferred to scintillation vial containing $2 \mathrm{ml}$ of ethanol and $10 \mathrm{ml}$ of toluene scintillant, and radioactivity was measured in a Beckman LS-150 counter. The results were expressed as nmoles of $\mathrm{CO}_{2}$ released per $10^{6}$ cells.

${ }^{125}$ I-mEGF binding assay. Radiolabeling of mouse epidermal growth factor (mEGF, Collaborative Research, receptor grade) with $\mathrm{Na}{ }^{125} \mathrm{I}$ (New England Nuclear, carrier free) was done using the method of DeLarco et al. ${ }^{13)}$ and the binding assay was done by the method of Todaro et al. ${ }^{14)}$ RME-5-3-1 cells or HeLa cells were cultured $\left(2 \times 10^{4}\right.$ cells $/ 16 \mathrm{~mm}$ well, in $1 \mathrm{ml}$ of $10 \%$ calf serum containing DMEM) at $37^{\circ} \mathrm{C}$ for $48 \mathrm{hr}$, and the medium was then renewed. After $24 \mathrm{hr}$ of cultivation, the medium was again replaced by the same new medium, or by a medium containing an appropriate amount of PI, TPA $(500 \mathrm{ng} / \mathrm{ml})$, or both the cells were cultured $5 \mathrm{hr}$ more, and the cells were washed twice with $1 \mathrm{ml}$ of the binding buffer. ${ }^{14)}$ The binding assay was done for $60 \mathrm{~min}$ at $20^{\circ} \mathrm{C}$ by the addition of $3 \mathrm{ng}$ of ${ }^{125} \mathrm{I}$-mEGF (containing approximately $167,000 \mathrm{cpm}$ ) in $0.2 \mathrm{ml}$ of binding buffer. The ${ }^{125} \mathrm{I}$-mEGF-treated cells were washed four times with $0.5 \mathrm{ml}$ of binding buffer and were solubilized in $0.5 \mathrm{ml}$ of the lysing buffer, ${ }^{14)}$ and the contents were transferred into counting tubes. The radioactivity was measured with a gamma counter (Aloka TDC-501). 


\section{RESULTS}

Effects of PI on the proliferation of cultured cells

Both of the RME-5-3-1 and Culb TC/R/TC cells showed almost no proliferation during $72 \mathrm{hr}$ of cultivation with $100 \mu \mathrm{g} / \mathrm{ml}$ of PI in the medium, with medium renewals at $24 \mathrm{hr}$ intervals. At the PI concentrations below $50 \mu \mathrm{g} / \mathrm{ml}$, however, the growth curves of the both cell lines ran nearly parallel with but slightly lower than that of the control. As seen in Fig. 1, the proliferation rates recovered upon the exclusion of PI from the medium at $24 \mathrm{hr}$ of the cultivation of RME-5-3-1 cells in PI-containing medium $(100 \mu \mathrm{g} / \mathrm{ml})$. It is suggested that the effect of PI on the cell proliferation is temporary and reversible, without functional damage to the cells.

Effects of PI on plasmin activation by RME-51/TMT cells

The production of plasminogen activator ${ }^{15)}$ by malignant RME-5-1/TMT cells was confirmed by the clearing of the cloudy fibrinagarose overlay on the cultured cells, in the fibrin-agarose overlay method. ${ }^{5)}$ With more than added PI $12.5 \mu \mathrm{g} / \mathrm{ml}$, however, no clarification of the overlay was observed, indicating the suppression of the plasmin activity. The concentration required for the suppression seems heigher than that was found in a previous experiment for the direct antiplasmin activity $\left(\mathrm{ED}_{50}=2.5 \mu \mathrm{g} / \mathrm{ml}\right)$ using the esterolytic activity of plasmin as a marker, on tosylarginine methyl ester. ${ }^{1)}$

\section{Effects of PI on ODC activities}

The extract of RME-5-3-1 cells $\left(10^{6} / 100 \mathrm{~mm}\right.$ dish), cultured for $6 \mathrm{hr}$ from the quiescent state in normal medium, was incubated in the presence of PI, and released ${ }^{14} \mathrm{CO}_{2}$ was measured. PI inhibited ODC activity directly by $\mathrm{ED}_{50}=$ $20 \mu \mathrm{g} / \mathrm{ml}$. Also, the effect of PI on the cellular ODC activity was examined by cultivation of RME-5-3-1 cells in the medium containing PI at in various concentrations. At times the treated cells were collected and ODC activity

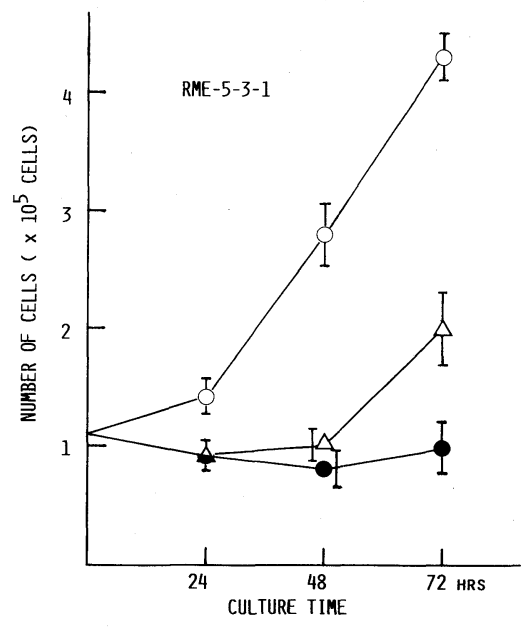

FIG. 1. Recovery from Growth Inhibition after Removal of PI from a Culture of RME-5-3-1 Cells.

RME-5-3-1 cells were grown at $37^{\circ} \mathrm{C}$ in PI-free medium (O), PI-containing medium $(100 \mu \mathrm{g} / \mathrm{ml}$; $\bigcirc)$, or with medium exchange at $24 \mathrm{hr}$ intervals from PI-containing to PIfree medium $(\triangle)$. The numbers of viable cells were counted at intervals with Crystal Violet staining. Whiskers indicate maximum and minimum counts.

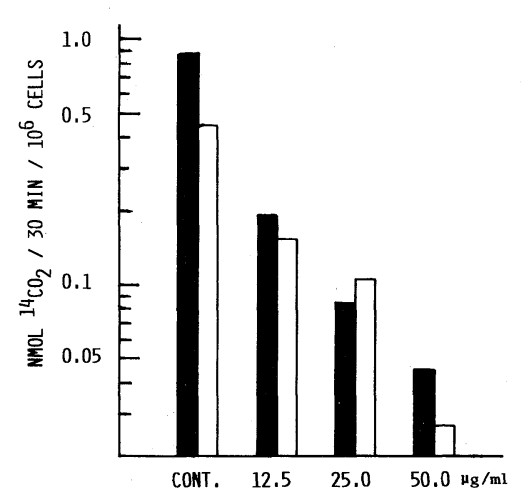

FIG. 2. Inhibition by PI of Cellular ODC Activity.

Quiescent RME-5-3-1 cells were cultured at $37^{\circ} \mathrm{C}$ in media containing various concentration of $\mathrm{PI}$, and the ODC activities were measured at $4 \mathrm{hr}$ (closed column) and $8 \mathrm{hr}$ (open column) of cultivation. The radioactivities of released ${ }^{14} \mathrm{CO}_{2}$ from $\mathrm{DL}-\left[1-{ }^{14} \mathrm{C}\right]$-ornithine by inoculation with the cell extracts were measured by trapping with ethanolamine.

of their extracts was measured. As seen in Fig. 2 , cellular ODC activities in the treated cultures were dose-dependently reduced in the media containing PI at concentrations between $12.5 \mu \mathrm{g} / \mathrm{ml}$ to $50 \mu \mathrm{g} / \mathrm{ml}$, after both 4 and $8 \mathrm{hr}$. 


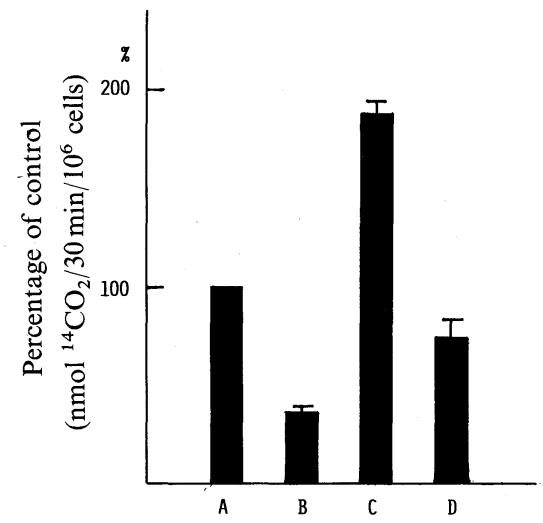

FIG. 3. Suppression by PI of the Increase of ODC Activity Induced by TPA.

Quiescent RME-5-3-1 cells were cultured with media containing PI $(12.5 \mu \mathrm{g} / \mathrm{ml})$ and $/$ or TPA $(500 \mathrm{ng} / \mathrm{ml})$. (A) control, (B) in PI-containing medium, (C) in TPAcontaining medium, and (D) in (PI + TPA)-containing medium. and ODC activities were measured, by the same method $s$ in the Fig. 2, at $6 \mathrm{hr}$ of cultivation.

\section{Effects of PI on TPA-induced ODC enhance- ment}

We did an experiment on counteraction of TPA and PI, in which RME-5-3-1 cells were cultured in the media containing PI $(12.5 \mu \mathrm{g} /$ $\mathrm{ml}$ ) and/or TPA $(500 \mathrm{ng} / \mathrm{ml})$, in the same manner as above. As seen in Fig. 3, the ODC activity was decreased by treating the cells with medium containing PI alone, but was greatly increased by cultivation in TPA medium without PI, both after $6 \mathrm{hr}$ of cultivation. When PI was present along with TPA, the TPA-induced increase of ODC were significantly suppressed, nearing the control level. These results were in accord with assumption of the counteraction between TPA and PI.

\section{Influence of PI and/or TPA on ${ }^{125}$ I-mEGF binding ability of cells}

To examine the reciprocal action between PI and TPA on the variation of EGF-binding ability of cells, we first examined the effects of TPA and/or PI on the binding ability of RME5-3-1 cells by precultivation for 3 days in normal medium and treatment with media containing TPA and/or PI for $5 \mathrm{hr}$. No influence of PI on the binding ability was observed

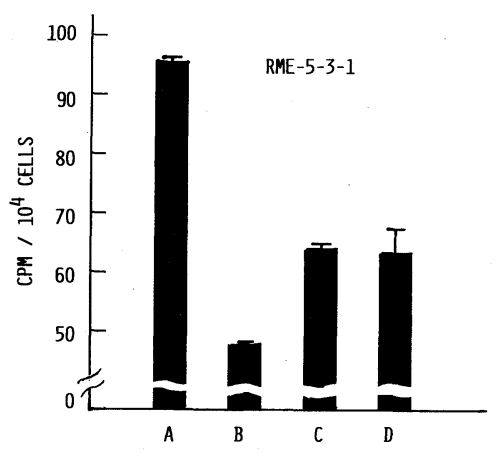

FIG. 4. Reversal by PI of the TPA-induced Decrease of ${ }^{125}$ I-mEGF-binding Ability of RME-5-3-1 Cells.

RME-5-3-1 cells were cultured for $5 \mathrm{hr}$ at $37^{\circ} \mathrm{C}$ in (A) blank medium, or in media containing (B) $500 \mathrm{ng} / \mathrm{ml}$ TPA (C) $500 \mathrm{ng} / \mathrm{ml} \mathrm{TPA}$ and $12.5 \mu \mathrm{g} / \mathrm{ml} \mathrm{PI}$, and (D) $500 \mathrm{ng} / \mathrm{ml}$ TPA and $25.0 \mu \mathrm{g} / \mathrm{ml}$ PI. These cultured cells were treated with $0.2 \mathrm{ml}$ of ${ }^{125} \mathrm{I}-\mathrm{mEGF}$ containing buffer $(3 \mathrm{ng} / 0.2 \mathrm{ml}$, about $167,000 \mathrm{cpm}$ ) at $20^{\circ} \mathrm{C}$ for $60 \mathrm{~min}$, and the radioactivities of the treated cells were counted with a gamma counter.

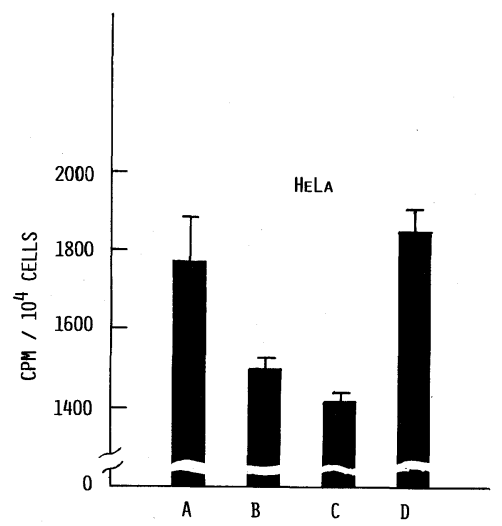

FIG. 5. Reversal by PI of the TPA-induced Decrease of ${ }^{125}$ I-mEGF-binding Ability of HeLa Cells.

HeLa cells were cultured for $5 \mathrm{hr}$ at $37^{\circ} \mathrm{C}$ in (A) plain medium, or in media containing (B) PI, (C) TPA, and (D) TPA and PI. Concentrations: TPA $500 \mathrm{ng} / \mathrm{ml}$, PI $12.5 \mu \mathrm{g} / \mathrm{ml}$. The EGF-binding assay was the same as in Fig. 4.

with media containing $12.5 \mu \mathrm{g} / \mathrm{ml}$ or 25.0 $\mu \mathrm{g} / \mathrm{ml}$ PI. TPA in the medium $(500 \mathrm{ng} / \mathrm{ml})$ decreased the ${ }^{125}$ I-mEGF-binding ability (Fig. 4B). With cells treated with the medium containing both TPA $(500 \mathrm{ng} / \mathrm{ml})$ and PI (12.5 $\mu \mathrm{g} / \mathrm{ml}$ or $25.0 \mu \mathrm{g} / \mathrm{ml})$, the decrease of EGFbinding ability by TPA was partially reversed by PI (Fig. 4C, D). 
In another set of experiments, HeLa cells were used instead of RME-5-3-1 cells, as a representative example of a malignant cell line having high EGF-binding ability. As seen in Fig. 5, the results were very different from those obtained for RME-5-3-1 cells; both TPA and PI decreased the EGF-binding ability (Fig. 5B, C), but their simultaneous presence in the medium seemed to cancel each other's activity (Fig. 5D).

\section{DISCUSSION}

Our preliminary examination of the effects of PI on in vitro growth of animal cells found inhibition at concentrations above $50 \mu \mathrm{g} / \mathrm{ml}$. However, this inhibition was not specific to malignant cells and the growth had recovered to similar to the normal rate $24 \mathrm{hr}$ after the replacement of PI-containing medium by normal medium, which suggested that the activity of PI is essentially not cytotoxic. We accordingly examined the influence of PI on the in vitro phenotypic expression of animal cells, native or TPA-induced. PI suppressed the native plasmin- and ODC activities in the cells, the TPA-induced increase of ODC activity, and also the TPA-induced decrease of ${ }^{125} \mathrm{I}$ mEGF-binding ability of the cells.

As has been described, the observed restorative effect of PI on the TPA-induced suppression of EGF-binding ability of HeLa cells was much greater than on RME-5-3-1 cells. It is very probable that this case is an additional example of the cell strain-dependent behavior of the EGF receptors that have been frequent reported and that have been attributed to the quantitative and qualitative differences of the receptor from cell to cell. ${ }^{11 \sim 16,25)}$

It is unlikely that the apparently interactive action between TPA and PI observed is due to their chemical interactions, considering their chemical properties. As polyphenols show high affinities to proteins and are often bioactive due to these affinities, it is more reasonable to consider that the apparent interaction is physiological.

In this connection, Nishizuka ${ }^{26)}$ has sug- gested that TPA binds with and activates protein kinase $\mathrm{C}$ on the cell membrane. More recently other workers also has suggested that activated kinase $\mathrm{C}$ is involved in ODC induction and the decrease of EGF-binding ability. ${ }^{27 ~ 29)}$ These observations and the results of our study may be in some way related to each other by future studies.

The observed bioactivities of PI on in vitro animal cells are at least in accord with the supposition that PI suppresses TPA-induced tumor promotion, even though it is too early to relate them directly to its previously observed effect on Ehrlich carcinoma.

Acknowledgments. The authors thank the late Professor H. Katsuta and Professor M. Umeda for their kind gift of cell lines, and Dr. Tsuji of the Institute of Physical and Chemical Research for his help in manuscript preparation, and also Eisai Co., Ltd. for their help in supplying the materials.

Some of this work was done as part of the international collaboration program concerning bioactive substances in tropical plants between the Institute of Physical and Chemical Research and Padjadjaran University, Indonesia, and was also supported in part by the Special Research Program in Life Sciences. Both programs have been financially supported by the Science and Technology Agency of the Japanese government.

\section{REFERENCES}

1) S. Takeuchi, Y. Kono, Hadiman, T. Mizutani, K. Maruyama, R. Nakayama, A. Hiraoka, Y. Suzuki, R. Watanabe, A. Kawarada and S. S. Adisewojo, Agric. Biol. Chem., 50, 569 (1986).

2) J. C. Unkeless, A. Tobia, L. Ossowski, J. P. Quigley, D. B. Rifkin and E. Reich, J. Exp. Med., 137, 85 (1973).

3) L. Ossowski, J. C. Unkeless, A. Tobia, J. P. Quigley, D. B. Rifkin and E. Reich, J. Exp. Med., 137, 112 (1973).

4) Christman and G. Acs, Biochim. Biophys. Acta, 340, 339 (1974).

5) P. Jones, W. Benedict, S. Strickland and E. Reich, Cell, 5, 323 (1975).

6) W. E. Lang, P. A. Jones and W. F. Benedict, J. Natl. Cancer Inst., 54, 173 (1975).

7) A. E. Cress and E. W. Gerner, Biochem. J., 88, 375 (1980).

8) D. H. Russel and S. H. Snyder, Proc. Natl. Acad. Sci. U.S.A., 60, 1420 (1968).

9) P. Jänne, H. Pösö and A. Raina, Biochim. Biophys. Acta, 473, 241 (1978). 
10) K. Rothlels and R. C. Parker, J. Exp. Zool., 142, 507 (1959).

11) E. D. Adamson and R. R. Anthony, Mol. Cell Biochem., 34, 129 (1981).

12) Carpenter and S. Cohen, Ann. Rev. Biochem., 48, 193 (1979).

13) J. E. DeLarco, R. Reynold, K. Carlbeg, C. Engle and G. J. Todaro, J. Biol. Chem., 255, 3685 (1980).

14) G. J. Todaro, J. E. DeLarco and S. Cohen, Nature (London), 264, 26 (1976).

15) J. Blomberg, F. H. Reynolds Jr., W. J. M. Van de Ven and J. R. Stephenson, Nature, 286, 504 (1980).

16) T. Nambata, N. Terada, T. Mizutani and S. Takeuchi, Gann, 73, 592 (1982).

17) S. H. Yuspa, N. Colburn and W. Kelsey, Nature, 262, 402 (1976).

18) P. M. Blumberg, P. E. Driedger and P. W. Rossow, Nature, 264, 446 (1976).

19) P. E. Driedger and P. M. Blumberg, Cancer Res., 37, 3257 (1979).

20) M. Shoyab, J. E. DeLarco and G. J. Todaro, Nature,
279, 387 (1979).

21) M. Wigler and I. B. Weinstein, Nature, 259, 232 (1976).

22) L. Beguinot, J. A. Hanover, S. Ito, N. D. Richart, M. C. Willingham and I. Pastan, Proc. Natl. Acad. Sci. U.S.A., 82, 2774 (1985).

23) H. Katsuta and T. Takaoka, J. Natl. Cancer Inst., 49, 1563 (1972).

24) T. G. O'Brien, R. C. Simsiman and R. K. Boutwell, Cancer Res., 35, 1662 (1975).

25) Y. Xu, N. Richart, S. Ito, G. T. Merlino and I. Pastan, Proc. Natl. Acad. Sci. U.S.A., 81, 7308 (1984)

26) Y. Nishizuka, Nature, 308, 693 (1984).

27) C. Cochet, G. N. Gill, J. Meisenhelder, J. A. Cooper and T. Hunter, J. Biol. Chem., 259, 2553 (1984).

28) S. Iwashita and C. F. Fox, J. Biol. Chem., 259, 2559 (1984).

29) A. M. Jetten, B. R. Ganog, G. R. Vanderbark, J. E. Shirley and R. M. Bell, Proc. Natl. Acad. Sci. U.S.A., 82, 1941 (1985). 